\title{
Study on the Construction of Performance Management Assessment Index System in the Post Management Background
}

\author{
Xiaoli Zhang \\ The Personnel Department \\ Jilin Business and Technology College \\ Changchun, China
}

\begin{abstract}
With the deepening of the post management in colleges and universities, The drawbacks of the old management mode in universities are gradually revealed, such as the assessment system is not perfect, the assessment method is single, the assessment indicators are not scientific enough, and the assessment results are not fully utilized. Faced with increasing competitive pressure under the new situation, colleges and universities need to enhance their competitiveness through efficient, professional management mode and management methods. So, this paper puts forward the idea of establishing the college's performance management mode under the background of post management. According to the management characteristics of colleges and universities, this paper makes an adjustment to the balanced scorecard theory which successfully applied to corporate performance management. Based on the key performance index method as the theoretical basis of college performance management, the paper tries to finish the design of the key index system of college performance management. It has some guiding significance for the implementation of college performance management under the background of post management.
\end{abstract}

Keywords-college; post management; performance management

\section{INTRODUCTION}

The reasons to the implementation of post management of colleges and universities, on the one hand is to carry out the national institution management policy, implement business unit personnel management scientific, standardized and institutionalized, on the other hand is also the school's development goal and staff personal development goals closer together. According to the school's overall development goal setting mechanism, setting up post, making job management manual, and evaluating according to the job management manual, Stimulate the work enthusiasm of the faculty, and realize the overall development goal of the school college. It can be seen that the goal of the objective of the management of the university is consistent with corporate performance management. The

Project: The higher education research project of the higher education society of Jilin province in 2017 "Research on performance management system and information technology of local universities in Jilin province" (JGJX2017D251) connection between the two is shown in the following aspects.

- In college post management and enterprise performance management, the realization of individual goals of employees is realized by making positive contributions to the overall development goals of universities or enterprises. Overall development goals and personal development goals are mutually compatible.

- Universities and enterprises both have their own mission or development strategies and are supported by employees.

- Although the value of universities and teachers is more reflected in training talents, scientific research and social services, But like enterprise and enterprise employees, its most immediate value is reflected in "benefits", including social benefits, economic benefits and salary levels.

- The primary tasks of universities and enterprises are to meet the needs of "customers", but the customers that colleges and universities face are special, including direct customers and the ultimate customer society. College customers, including students who are their direct customers and society which is their ultimate customer.

- Whether it is the job management of the university or the management of enterprise performance, it is necessary to keep up with The Times. And constantly adjusting and improving internal management, the subject of management should also keep learning and growing.

\section{SElECTION OF COLlege PERFORMANCE} MANAGEMENT METHODS IN THE CONTEXT OF POST MANAGEMENT

Although there are many similarities between the management of university post and the management of corporate performance, the difference is greater. In order to realize the college performance management under the 
background of post management, it is not feasible to carry out the successful performance management theory and model of a certain enterprise. Through the analysis of the present situation and problems of college performance management, the author analyzes and contrasts several performance theories that are successful in enterprise practice. In combination with the characteristics of university management, any theory applied to the performance management of colleges and universities is deficient.

Therefore, this paper proposes that the four dimensions of the balanced scorecard method be transformed according to the characteristics of university management, and then combined with the key performance indicators to guide the theory, setting up the performance management index system in the background of post management.

\section{A. Conversion of Financial Dimension to Contribution Recognition Dimension}

Colleges are non-profit organizations. On the one hand, the financial goals of colleges and universities are not directly accomplished by teachers. On the other hand, financial goals are not as dominant as enterprises in the development strategy of universities. In the strategic goals of universities, the dominant position is social recognition and social acceptance. Such as students' social needs, research achievements and social needs of teaching and research results, etc. Therefore, in the college performance management system, the enterprise needs to translate the financial dimension of the balanced scorecard into the dimension of contribution recognition.

\section{B. Transformation of Ordinary Customer Dimension to Special Customer Dimension}

The customer dimension of enterprise performance management is very important because the financial goals and development strategy of the enterprise are realized through the purchase of the products by the customers. The customers and products facing universities are very special. The most direct customers are students, who themselves are the "products" of the university. The society is the ultimate customer of the university, the strategic goal of the university is finally realized through the service society.

\section{The Internal Process and Learning and Growth Dimensions}

They are the same in the performance management of enterprises and colleges, and no need to convert again. The corresponding performance indicators should be adjusted according to the specific situation.

\section{FORMULATING THE INDEX SYSTEM OF PERFORMANCE MANAGEMENT IN COLLEGES AND UNIVERSITIES IN COMBINATION WITH POST MANAGEMENT}

\section{A. Establishment of the University Performance Management Model}

According to the target of university post management, the adjusted balanced scorecard theory and key performance index method are combined to guide the establishment of the university performance management model, as shown in "Fig. 1":

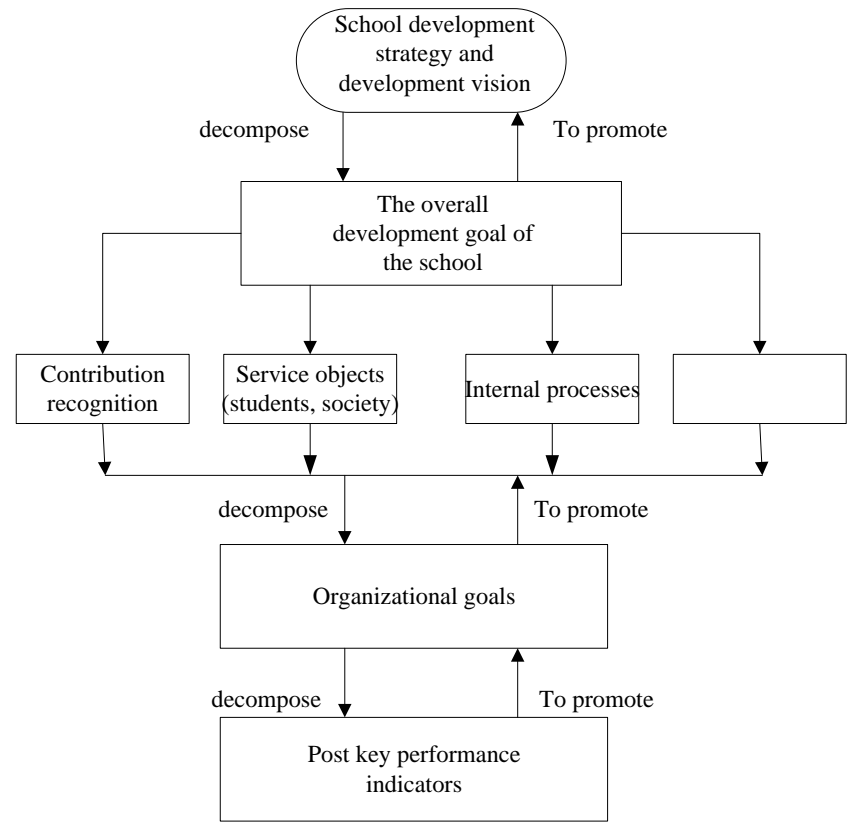

Fig. 1. Performance management model of general colleges and universities.

\section{B. Establishment of Key Indicators System of Performance Management in Universities}

1) Determination of the school performance assessment index system: The production of school performance indicators should be guided by mature and clear strategic objectives.

This paper, taking the development strategy goal of ordinary universities as an example, breaks down the index system of performance assessment of ordinary colleges and universities, as shown in "Table I":

TABLE I. SCHOOL PERformance AsSESSMENT INDEX SySTEM

\begin{tabular}{l|l}
\hline \multicolumn{1}{c|}{ Primary index } & \multicolumn{1}{c}{ Secondary index } \\
\hline Development strategy & $\begin{array}{l}\text { School-running thoughts } \\
\text { School localization }\end{array}$ \\
\hline \multirow{3}{*}{ Team construction } & $\begin{array}{l}\text { construction of teaching staff } \\
\text { construction of Management team } \\
\text { construction of Research team }\end{array}$ \\
\hline \multirow{2}{*}{$\begin{array}{l}\text { Construction of school } \\
\text { conditions }\end{array}$} & $\begin{array}{l}\text { Basic facilities for teaching and management } \\
\text { fund investment } \\
\text { Research platform construction }\end{array}$ \\
\hline \multirow{3}{*}{ Ethos construction } & $\begin{array}{l}\text { Management culture } \\
\text { Teaching atmosphere } \\
\text { Learning ethos (faculty, students) }\end{array}$ \\
\hline \multirow{3}{*}{ Social influence } & $\begin{array}{l}\text { udent quality (knowledge level, practical } \\
\text { ability) and } \\
\text { Student employment rate } \\
\text { Teaching and research awards and } \\
\text { achievements transformation } \\
\text { Social reputation } \\
\text { Special item }\end{array}$ \\
\hline
\end{tabular}


2) Determination of the performance evaluation index system of organizational institutions: Through the college performance management model, it can be seen that, after the overall goal of the school is determined. Under the guidance of the balanced scorecard theory, the overall goal of the school is divided into the next level of organization of the school through the contribution of recognition, service object, internal process, and learning and growth dimension. Then form an organizational performance assessment index system. As shown in "Table II":

TABLE II. PERFORMANCE APPRAISAL INDEX SYSTEM OF ORGANIZATIONAL INSTITUTIONS

\begin{tabular}{|c|c|}
\hline The dimension & $\begin{array}{c}\text { Organization performance appraisal index } \\
\text { system }\end{array}$ \\
\hline $\begin{array}{l}\text { Contribution } \\
\text { recognition }\end{array}$ & $\begin{array}{l}\text { Appropriation rate (use of funds/( To the } \\
\text { account funds + schools appropriation)) } \\
\text { Work efficiency (actual number of } \\
\text { working/approved posts) } \\
\text { Overall structure status and development trend } \\
\text { (level of education level, professional title } \\
\text { level) } \\
\text { Business level } \\
\text { The quality of service }\end{array}$ \\
\hline $\begin{array}{l}\text { Service objects such } \\
\text { as students, faculty, } \\
\text { society, etc }\end{array}$ & $\begin{array}{l}\text { Student satisfaction } \\
\text { Faculty satisfaction } \\
\text { Student employment rate and social acceptance } \\
\text { Scientific research achievements } \\
\text { Scientific research awards }\end{array}$ \\
\hline Internal processes & $\begin{array}{l}\text { The system construction } \\
\text { Environmental construction (work } \\
\text { environment, school environment, scientific } \\
\text { research environment, promotion environment) } \\
\text { Atmosphere construction } \\
\text { Management process }\end{array}$ \\
\hline Learning and growth & $\begin{array}{l}\text { Spiritual construction } \\
\text { Responsibility consciousness } \\
\text { Echelon construction (educational echelons, } \\
\text { titles and echelons) } \\
\text { Improved professional knowledge level }\end{array}$ \\
\hline
\end{tabular}

3) Determination of the indicator system of postperformance assessment: The reason why colleges and universities should implement performance management is to enhance the enthusiasm of teaching workers by stimulating the work of teachers and the enthusiasm of the school .Eventually, the school will continue to develop towards higher strategic goals.

Therefore, the key indicators should be more specific and easier to understand and operate. In addition, after the implementation of post management, the job description is the cornerstone of performance management in colleges and universities. Therefore, the key indicators of postperformance should be used as the basis for the job description, such as the job objective, the main work content, the position authority and the position qualifications, etc. According to the above characteristics, the indicator system of job performance assessment is shown in "Table III":
TABLE III. Post Performance Assessment Index System

\begin{tabular}{c|l}
\hline \multicolumn{1}{c|}{ Primary index } & \multicolumn{1}{c}{ Secondary index } \\
\hline \multirow{5}{*}{ Comprehensive quality } & $\begin{array}{l}\text { Behavior and moral character } \\
\text { Degree qualifications } \\
\text { Business level } \\
\text { Sense of responsibility } \\
\text { Work attitude }\end{array}$ \\
\hline teaching & $\begin{array}{l}\text { The teaching method } \\
\text { Teaching workload } \\
\text { The quality of teaching }\end{array}$ \\
\hline \multirow{3}{*}{ The scientific research } & $\begin{array}{l}\text { High level academic papers } \\
\text { Teaching, research project level } \\
\text { Teaching scientific research project funds } \\
\text { Scientific research awards } \\
\text { Scientific research achievements }\end{array}$ \\
\hline service & $\begin{array}{l}\text { Construction of facilities } \\
\text { Environment construction } \\
\text { Platform construction } \\
\text { The quality of service }\end{array}$ \\
\hline Special contribution & \\
\hline 4) Allocation of key index weights: Weight is also
\end{tabular}
known as weight, which refers to the proportion of an evaluation index in the overall assessment result. Therefore, the determination of weight in the performance management index system is also especially critical. At present, the application of mature weight determination method has expert weighting method, defel consulting, simple comparison and so on. In this case, the defield method adopted the advice of repeated consulting experts, and made statistics by the planners until it reached the weight of the unified scheme. The method is simple, scientific and practical.

Therefore, this paper puts forward the distribution of weight distribution using defel, and the specific formula is expressed as follows:

$\mathrm{Yi}=(\mathrm{Y} 1+\mathrm{Y} 2+\mathrm{Y} 3) / 3 \quad \mathrm{Ym}=(\mathrm{P} 1 \mathrm{i}+\mathrm{P} 2 \mathrm{i}+\mathrm{P} 3 \mathrm{i}+\mathrm{P} 4 \mathrm{i}+\ldots+\mathrm{Pni}) / \mathrm{n}$ $\mathrm{n}$ is the number of experts and $\mathrm{m}$ is the number of rounds;

$\mathrm{Yi}$ is the score of the I index;

$\mathrm{Y} 1, \mathrm{Y} 2, \mathrm{Y} 3$ is the score of the ith index $\mathrm{m}$;

P1i, P2i, P3i,...Pni is the NTH expert's score on the ith index.

Undergoes The Repeated Test, Finally, the weight of the post assessment index is shown in "Table IV". 
TABLE IV. WeIGHT OF PERFoRMANCE APPRAISAL INDEX SySTEM

\begin{tabular}{|c|c|c|c|}
\hline Primary index & The weight & Secondary index & The weight \\
\hline Comprehensive quality & 0.2 & $\begin{array}{l}\text { Behavior and moral character } \\
\text { Degree qualifications } \\
\text { Business level } \\
\text { Sense of responsibility } \\
\text { Work attitude }\end{array}$ & $\begin{array}{l}0.2 \\
0.15 \\
0.2 \\
0.2 \\
0.25\end{array}$ \\
\hline Teaching & 0.3 & $\begin{array}{l}\text { The teaching method } \\
\text { Teaching workload } \\
\text { The quality of teaching }\end{array}$ & $\begin{array}{l}0.3 \\
0.4 \\
0.4\end{array}$ \\
\hline The scientific research & 0.2 & $\begin{array}{l}\text { High level academic papers } \\
\text { Teaching, research project level } \\
\text { Teaching scientific research project funds } \\
\text { Scientific research awards } \\
\text { Scientific research achievements }\end{array}$ & $\begin{array}{l}0.2 \\
0.3 \\
0.35 \\
0.15 \\
0.1\end{array}$ \\
\hline Service & 0.2 & $\begin{array}{l}\text { Construction of facilities } \\
\text { Environment construction } \\
\text { Platform construction } \\
\text { The quality of service }\end{array}$ & $\begin{array}{l}0.2 \\
0.3 \\
0.3 \\
0.2\end{array}$ \\
\hline Special contribution & 0.1 & & \\
\hline
\end{tabular}

\section{CONCLUSION}

The performance appraisal index system is the key link in the construction of the performance management system. In this paper, the balanced scorecard method is adjusted, and then combined with the performance shutdown index method is the theoretical basis. In combination with the background of university post management, the paper tries to construct the index system of college performance appraisal. From the theory and practice, the feasibility and necessity of the performance management in universities are proved.

\section{REFERENCES}

[1] Nie middle spring, du xiuxiu. Analysis on the construction and implementation of enterprise performance management [J]. Innovation and application of science and technology. 2015(17).

[2] Wang zhiguang. Problems and countermeasures in enterprise employee performance management [J]. Reading and writing (education teaching journal). 2015(05).

[3] Zhou zhi-long. Internal control and external responsibilities: objective positioning of government performance evaluation [J]. Journal of Beijing institute of electronic science and technology. 2015 (03). 